\title{
Study on Perception of Maternity in Eastern Philosophy — Centered on Kim Jiha's Poems*
}

\author{
Shuqing $\mathrm{He}$ \\ School of Humanities and Law \\ Hangzhou Dianzi University \\ Hangzhou, China
}

\begin{abstract}
Modern Western capitalism sets the material affluence and prosperity as the ultimate goal has affected people who are living today. They forget real human values and the meaning of life and thus live a life of alienation and loss in the blind accumulation of wealth and limitless competition. Since the modern age, many philosophies and ideas of the East and West have started from a willingness to criticize these modern problems and have been trying to overcome them. Korean Poet Kim Chi-ha is one of them. His literary works based on the Donghak thoughts from the Orient have been the major pathway by which we can estimate the development aspects of his resistance consciousness and revolution ideology.
\end{abstract}

Keywords—Kim Jiha; Eastern philosophy; ecofeminism; poetry

\section{INTRODUCTION}

Modern day's Western capitalism, of which the ultimate goal is to pursue material wealth and prosperity, has made people forget the true value of humans and the meaning of life, forcing them to live an alienated, depersonalized lifestyle in the midst of reckless accumulation of wealth and cutthroat competition. A variety of modern philosophies and thoughts originated from the determination to criticize and overcome these problems. One of these trends, western ecofeminism, views environmental and ecological destruction as the most serious abuse of the modern day, and has pointed out the underlying cause to be modern culture's male-centered develop mentalism. Ecofeminism asserts that for a harmonic coexistence between humans, and humans and nature, modern manhood characteristics such as competition, conquest and destruction must first quelled. It also states that it is necessary to establish feminine and maternal values characterized by communication and tolerance as an alternative to overcome modern civilization. Thus, ecofeminism came to the foreground amid skepticism about the modern male-centered develop mentalism, being regarded as Deep Ecology's criticism of industrialism and economic imperialism.

Though it was only in the modern era that the importance of ecology and the feminine value were brought up in the

*A Project Supported by Philosophy and Social Science Foundation of Zhejiang Province (Grant No. 18NDJC049YB); Scientific Research Fund of Zhejiang Provincial Education Department. (Grant No.Y201737639).
West, philosophies and thoughts containing these viewpoints have existed for a long time in the East. Idealizing the East's unique environmentally friendly lifestyle, these philosophies and thoughts equate the image of femininity with that of nature and emphasized the importance of feminine values.

In South Korea, the tradition of ecofeminism in Eastern philosophy and thought was particularly manifested in the Donghak ideology, which has explosively erupted during the transitional period up until modern times. The Donghak ideology, based on the Taoist's principle of Yin and Yang, separates the existential modes of all creations and the driving force of transformative change into Yin (negative) and Yang (positive), which symbolizes the woman and man, respectively. The ideology claims that utopia can be achieved through the nourishment of Yin, the feminine force. "Life Ideology" by poet Kim Jiha was the first developmental application of ecofeminism deriving from the Donghak ideology to the modern Korean society. Since the full-blown industrialization started in the 1960s, developmental thought of the modern West became established as a leading social ideology in Korea. Under the pretext of 'development', Korean society pursued only material wealth, resulting in the destruction of human dignity and ecological environments, and giving birth to social problems like loss of communal life and marginalization. This phenomenon was the product of the industrialization era, in which humans seemed to become separated from nature. The worldview of 'extreme Yang' has been constantly emphasized under capitalism and is also said to have been caused by the 'destruction of life by humans'. In opposition against the developmental dictatorship imposed by the authoritarian government in the 1970s, poet Kim Jiha, had led the resistant literature movement in Korea. He founded from the Donghak ideology a philosophical concept that he believed could guide Korean society in the right direction, and developed it into 'life ideology.' He compared the phenomenon of destruction of ecological life and disregard of human life, which resulted from the modernization of Korea, to the concept of 'when-Yang-live-Yin-die' in the principle of Yin-Yang. Kim Jiha upheld the Donghak ideology including 'ideology of veneration on three objects', 'maternity ideology' and 'a cataclysmic change by Yin' for further development, and led the 'self-restoration movement' as part of an effort to heal the social diseases caused by the 
modernization of Korea by instituting the 'maternal life view.'

Kim Jiha's literary works after the 1970s have served as an important window into his feelings about the developmental aspects of resistance and transformation ideology. His poems before the 1980s were focused on his feelings toward the revolutionary resistance against the authoritarian government of restoration, and also on the world of resistance manifested through the active political battle. Since the 1980s, this literary style made a dramatic change into becoming an ultimate exploration of the maternal world of tolerance and reconciliation and of the true nature of life, rather than the world of resistance and rebellion. Particularly, the Aerins series, in which his ideological transition was first revealed, provide clues for an in-depth understanding of Kim Jiha's literary world and ideology. The series deserves an extensive analysis, in that the poetical achievement has important meanings, which are helpful for close examination of the true nature of his alleged theory of 'life ideology' and the world of maternity.

In this study, the author intends to closely examine the ideological backgrounds that gave birth to Kim Jiha's perception of maternity in his 'life ideology', and to identify any possible implications from the inspection of modern Korea through this maternity concept. For this purpose, first, this study will analyze the relationship between the Donghak ideology and Kim Jiha's life ideology. Second, the study will examine the process through which the concept of maternity was formed based on the 'life ideology' by looking into the transformative phase of Kim Jiha's poetic world.

Discovering ways to increase a sense of communal solidarity by finding cultural common grounds has been one of the core issues intensively addressed in the discourse of the East Asian Community. This study is expected to provide meaningful implications through the examination of Kim Jiha's life ideology and the perception of Oriental maternity appearing in his poems, searching for common points in the perception about women within East Asia traditions, and to explore the cultural homogeneity and solidarity.

\section{DONGHAK IDEOLOGY AND POET KIM JIHA’S LIFE IDEOLOGY}

Kim Jiha's life ideology is closely related to a new enlightening realization he experienced while in prison. After he was freed in 1981, he named the title of his acceptance speech for the Lotus award as For Creative Reunification, which clearly showed his ideology of life and the recognition of dignity of life. (Han Myunghee 2009: 156.) He criticized the Western ideology, dominated by dichotomy and reductionism, for causing the masses to chase for lust and to worship the Mammon. He also lambasted Asia, Africa, and Latin America for 'rejecting life and subjecting themselves to the devilish tendency of destruction of life'. He stated that 'a new world view and a subsistence mode of life must be cultivated to achieve decisive fellowship and peace between human and self, human and human, and human and nature'. (Kim Jiha, 1984: 12-13.) Such clues to his ideology of life became systemized in his poem South, Daeseol in 1982, and expanded broadly and deeply through the publication of his collections of poems: Meal in 1984, Life in 1992, Life and Autonomy in 1996, and Life and Road to Peace in 2005, etc. (Han Myunghee 2009: 156.)

He considers all organisms and natural entities, such as inorganic substances, and even things like historical process, as having life. This life ideology is a progressive succession of the Donghak ideology. The very essence of the Donghak ideology is a mind that values life, or considers all things as having life, which is the core idea persistently pursued by the ideology. Considering inorganic substances and even inanimate objects as having life is a distinctive element of the Donghak ideology, which distinguishes itself from other ideas (Kang Chanmo 2006: 7.) Haewol's 'ideology of veneration on three objects' is a concretization of such consciousness, and among them, 'ideology of the veneration of inanimate objects' is the zenith of the veneration of life. Haewol states that 'human beings can achieve the height of morality, not by venerating other human beings, but by venerating even inanimate objects to achieve an oneness with the morality of Cheonjigihwa.' That is to say, the Donghak ideology considers all things in the universe as living entities, and simultaneously views them as an integrated whole and not just as a separate individual. (Kim Sangil 2004: 174.)

Haewol believed women could practice their life-oriented worldview by conceiving and giving birth to children. (Kim Jiha 1992: 33.) Conception can be said to be a concrete product and substance of 'Sicheonjoo (Serving God)', the main purpose of the Donghak ideology. The object of veneration in the Donghak ideology cannot be seen because it is an invisible, spiritual being. Therefore, it is advised that people should not be lazy in controlling and examining themselves through constant fellowship with the spiritual entities within themselves in order to live a spiritual and humble life. In other words, people always need to lead a respectful and cautious life so as not to hurt or abuse the spiritual entity. (Kang Chanmo 2006: 72.) Conception signifies a 'negative (Yin) symbol' belonging to a woman, since it is a concrete end result of the working of the spiritual force of life in a woman's body. Moreover, a woman's conception of life is considered to be the height of 'Sicheonjoo,' Kim Jiha, embracing the inclusive and reconciliatory worldview of conception, argues the following:

As mentioned before, conception is serving the universe as though it were her own parents. Since conception itself is already an activity that respectfully serves every life form in the universe, young housewives who experience 'veneration' and 'housework' on their own through conception need to step forward to lead this cultural movement, rather than merely shouting big words such as ecology, child care, education, infant life, etc. ... Since a woman's body and mind-set themselves are 'veneration,' won't such truthful and reverential 'veneration' be the genuine 'housework,' child rearing, and 'livelihood' of universal lives? - Life and Road to Peace, Moonji publishing co, 2005, pp. 32-33. 
Thus, Kim Jiha considers conception as the universal life force, and the conception of a child as the veneration of the universal life force and spirituality. The poet's dedication to the maternity that bears and delivers a life can be attributed to an enlightening experience that he had during his many years in prison. As he disclosed, those seven years in prison became a turning point (Kim Jiha 1992: 13) for him in regards to his thoughts. It seems that the time in prison gave him an opportunity to reexamine the ideal world he had been pursuing and to rediscover the true value of life.

It was springtime. One day, white dandelion flower seeds flew in and filled the prison cell, glittering and floating idly in the air. It was so beautiful. Dusts and soil particles were everywhere ... on the iron window bars, in crevices between the cement underlay and in the tiny holes dug by the force of rainfalls. Wind must have brought the grass seeds and dropped them in those holes, and soil particles and dusts too, to make seeds take roots and grow. The sun shone on that beautiful young grass... a word 'life' penetrated into my heart, freshly and brightly. - Life and Autonomy, Sol, 1996, p. 33 .

The long imprisonment served as an important turning point to help Kim Jiha re-recognize the value of life, even if it were to be that of a little dandelion or grass seed. He no longer considered the space called 'prison' as a discontinuation of life. $\mathrm{He}$ realized there is no discontinuation in life, and the concept of maternity, which brings about the conception of a new life, can be present in any space. In other words, the poet's self-conscious struggle to break through his isolated situation to reach a vast sea of life, without destroying his own life, caused him to become integrated with the socio-historical circumstances of human beings. (Shin Heungbeom 1985: 356.)

With this realization, Kim Jiha's life ideology became systemized through the developmental succession of the 'cataclysmic change by Yin' idea of the Donghak ideology. Kang Jeungsan's cataclysmic-change-in-Yin idea proposes a cataclysmic change through non-violence, which means a female-oriented cataclysmic change as opposed to a maleoriented cataclysmic change. It also proposes a chaotic change characterized by a disorganized order of the current age or coexistence, not by the cosmos, which is the order of the universe of the previous age', or polarity. (Kim Jiha 2005: 69.) Kim Jiha further developed Kang Jeungsan's idea of a cataclysmic change by Yin, to place an emphasis not on a female-oriented cataclysmic change but on the harmony and co-existence of Yin and Yang, especially the universal life principle embracing chaos and contradiction of the world. In this context, the current time is recognized as 'a cataclysmic change of the "current age, especially the age of 'cataclysmic change by the negative (Yin).'

For the past several thousand years, the history of the civilizations in the West and East was that of polarity, oppression, exploitation and war, and also that of 'suppressing Yin \& lifting Yang' under the dominant theory that "You're not me and I'm not you. You and I fight constantly, though you and I can unite temporarily. However, either you or I will have to prevail over each other to be united into one under the winner.' Nevertheless, since the dualism of heaven and earth, co-existence and incompatibility, men and women, and Yin and Yang is officially recognized, now is the time for the world to 'tip that balance to the other side,' which means the world of 'Joyangyooleum (control Yang \& put Yin to dance)' for the coexistence of the two opposing poles. - Life and Road to Peace, Moonji publishing co, 2005, pp. 73.

Though 'Yang' has been the dominant force in the current era, the coming era is expected to emphasize the harmony and fusion of Yin and Yang, that is, an era of life in which all things in the universe constantly move forward to become a single organic body through the idea of 'controlling Yang \& putting Yin to dance' in this malecentered world. Therefore, the most important factor for this era of life is the woman, who is the producer and fosterer of all forms of life, and which is considered as a synonym for 'life'.

So far, we have examined the Donghak ideology and Kim Jiha's life ideology. Among the Donghak ideology, Kim Jiha upheld and further developed the 'idea of veneration on three objects': the 'idea of serving', the 'idea of a cataclysmic change of the current age', and particularly the 'idea of a cataclysmic change by Yin'. He recognized 'life' as the origin of every existence in the world, and understood every process as a moving process of 'life'. (Park Inseong 1985: 165.) The mother-earthly origin of such lifecentered awareness is the maternity that has the ability to conceive life. As mentioned above, Kim Jiha's literary world before the Aerin series was centered on the concept of revolutionary resistance and active political resistant movements; the world of Yang. The poet's feelings regarding resistance and protest went through a distinct transformation over the course of seven years in prison. Starting from the Aerin series, his world changed from Yang, a world of oppression and fighting back, to Yin, a world of reconciliation and convergence.

In the next chapter, we are going to examine the manifestation of such transformations in his poetic works, particularly the Yin images revealed in the Aerin series, and also a world of 'active nothingness', a world of the maternity that is eventually formed through the fusion and transcendence of Yin and Yang.

\section{CONCLUSION}

The industrialized civilization of modern capitalism has pursued only the accumulation of wealth and material prosperity through unlimited competition, where the weak are the prey of the strong. The modern day value system brought to human societies the destruction of ecosystems and the collapse of the communal order, resulting in serious social problems like human alienation, etc. In both the East and West, modern philosophies and ideologies have taken pains to overcome such problems and hoped to create an ideal cultural society with a central point focused on humans. Of these philosophies, women-centered world views like ecofeminism, which aims to overcome the modern lifedestroying culture through criticism of the male-centered 
modern system and renewed awareness of the feminine value, has emerged in the West. However, these approaches are still bound by the dichotomic perspective, which is a problem of the modern era, and involve the possibility of reproducing the man vs. woman confrontational scenario. Emphasizing the feminine value as an alternative to coping with modern problems has become an irreversible trend, but we still have a long way to go until this trend actually becomes a cultural force bringing about post-modernism.

In connection with this critical mind, Kim Jiha's life ideology and recognition of maternity seem well worth the attention, in that he has provided clues to expand feminine values into a more deepened consciousness. Kim Jiha, based on Eastern thought which regards the harmonious integration of Yin and Yang as the reason behind the cosmic and life order, presents the future of human civilization through the discovery of maternity, which transcends the dichotomic disintegration of women and men. It transcends the material civilization culture of the modern capitalistic society established on the basis of masculinity, and at the same time is pursuing the world of maternity, which is the order of universal life. Therefore, the maternity at the core of his life ideology is neither a masculine act of conquest and destruction nor a feminine rebellion against it, but is a concept that puts into practice the ecological civilization that integrates the whole universe.

It cannot be overlooked that the reason Kim Jiha's life ideology introduced the concept of maternity as the futuristic alternative solution in the comprehensive healing of humankind is because his ideology is rooted in Eastern philosophy. As mentioned above, his life ideology was formed by newly applying Korea's Donghak ideology, which inherited the tradition of Eastern philosophy and ideology, to modern day Korean society. Considering the fact that Kim Jiha's life ideology and understanding of maternity corresponds with today's ideological flow that has emerged as an alternative to the modern Western counterpart, it can be said that this is a project in need of more intense study.

The true nature of Aerin as revealed in Kim Jiha's Aerin series, or the Eastern idea of maternity, introduces the monistic view of life to present a world of 'active nothingness' unrestricted by anything, it is the ultimate life principle of the universe that aims for a world of freedom. In this sense, the Eastern concept of maternity suggests an interrelationship between mankind and nature, and expresses monistic viewpoints on the true nature of life. The monistic view of life, as a dynamic complex that transcends the traditional Western dualism, will serve as both ideological clues and foundation for 'ecology movement' and 'ecological protectionism,' which are all currently under heated discussions worldwide.

\section{REFERENCES}

[1] Kim Jiha, collected works, 2009 .

[2] Kang Chanmo (2006), Study on the Donghak ideology in Kim Jiha poems, Cheongju University, Graduate school, doctoral thesis.
[3] Kwakum, Sipwoodo, translated with notes by Lee Keeyoung (1995). Korean Buddhism Institute.

[4] Kwon youngmin (2002), Korean modern literary history 1, 2, Minumsa.

[5] Kim Sangil (2004), Donghak and traditional ideology, Mosineun saramdl.

[6] Kim Jaehong (1994), Critiques of Korean contemporary poets, Siwasihaksa.

[7] Oh Moonhwan (1996), Human is heaven, Sol. 